Recebido: $19 / 12 / 2016$

Aprovado: 25/04/2017

\title{
Quando as identidades se transformam em calabouços. Pos- colonialidade, teoria queer e crítica chicana em Gloria Anzaldúa
}

Rafael Antonio Rodrigues*

\begin{abstract}
Resumo: O seguinte artigo quer explorar as concepções teóricas e identitarias por detrás da célebre obra da ativista e pensadora chicana Gloria Anzaldúa: The Borderland /La Frontera: The New Mestiza(1987). Sua trajetória de vida nos remete a tempos, tradições e espaços identitarios - Mesoamerica, México, EUA - conflitantes e irreconhecíveis entre si, que produzem fissuras e desconcerto nos discursos essencialistas da identidade e da alteridade. Assim como outros autores pós-coloniais como Franz Fanon e Vidiadhar Naipaul, Anzanldúa, ao invés de frustrar-se e seguir na desesperada busca por uma humanidade branca euro-centrada, nos conduz a outro caminho em que as noções binárias e cartesianas do ser e do sujeito são desestabilizadas para dar lugar ao que chamamos aqui de Devir Mutante: uma diferença indizível e incessante que atravessa as fronteiras não permitidas do humano e do não humano. A autora aposta, assim, na construção de um homem (humano) plural e multifacetado que está para além da ordem identitaria colonial e do olhar inquisidor metropolitano, que procuram delimitar e fixar os movimentos imprecisos e contraditórios do desejo e da alteridade.
\end{abstract}

Palavras-chave: identidade; alteridade; devir

Abstract: The following article explores the theoretical and identity conceptions behind the famous work of the thinker and the chicana activist Gloria Anzaldúa: The Borderland: The New Mestiza (1987). Her life trajectory reminds us of times, traditions and identities spaces - Mesoamerica, Mexico, USA - that are conflicting and unrecognizable to each other, which produces fissures and disconcerts in the essentialist discourses of identity and otherness. Like other postcolonial authors such as Franz Fanon and Vidiadhar Naipaul, Anzanldúa, instead of being frustrated and pursuing the desperate quest for a eurocentred white humanity, this author leads us to another path where the binary and Cartesian notions of being and subjecting are destabilized to give way to what we call here Devir Mutante: an unutterable and unspeakable difference that crosses the boundaries of the human and nonhuman. The author, thus bets on the construction of a plural and multifaceted (human) man who is beyond the colonial identity order and the metropolitan inquisitive look that seeks to delimit and fix the imprecise and contradictory movements of desire and otherness.

Keywords: identity; otherness; to become (devir)

\footnotetext{
* Mestre em História pelo Programa de Pós-Graduação em História da Universidade de Brasília (PPG-HIS/UnB). E-mail:deviintoster@gmail.com
} 


\section{Homophobia: O medo do retorno}

Logo ao início de seu clássico livro Borderlands - La Frontera: The New Mestiza (1987), Gloria Anzaldúa, ao lecionar literatura chicana e teoria queer em uma faculdade estadunidense, nos conduz a uma experiência que teve com um de seus alunos heterossexuais dentro de sala de aula. ${ }^{1} \mathrm{O}$ estudante lhe questiona sobre o termo Homophobia: "Eu pensava que homofobia significava medo de voltar para casa após uma instancia no exterior." (Anzaldúa, 1987:20). ${ }^{2}$ A indagação do aluno faz com que a autora repense a palavra e coloque-a em outra perspectiva: além do medo e repulsa direcionados aos homossexuais, poderíamos pensar a homofobia também em relação ao medo de hibridizar-se, de transformarse, de entrar em contato com a alteridade e tornar-se outro?

Ora, todos aqueles que viajam que ousam sair do conforto de sua cultura ou país de origem para vivenciar uma experiência no estrangeiro, tanto no sentido literal quanto no metafórico, experiência como possibilidade de mudança, de colocar em suspensão os valores que estruturam sua cultura "originária" e imergir em um mundo até então estranho e desconhecido. Aí reside o perigo da viagem: deixar-se ser contaminado e modificado pelo outro. Como reagiriam nossos pares nacionais quando do retorno de uma longa temporada em outro país? Seríamos reconhecidos como os mesmos de antes ou passaríamos a portar conosco o estigma da diferença?

O escritor trinitino Vidiadhar Surajprasad Naipaul, em seu livro Os Mímicos (1987), nos fala a respeito desta interrogante. Depois de haver concluído sua temporada de estudos em Londres e ter que regressar ao seu país natal, a ilha imaginária Isabella, Ralph Singh, o protagonista-narrador da obra, é tomado por uma sensação de angústia e apreensão. Mesmo desfeito a magia e o encantamento que o personagem atribuía à capital do império inglês, ele não consegue se identificar com a atmosfera e o mundo criados no país que o vira nascer. Aquele era o lugar da inautenticidade, do fingimento, da dissimulação. Como indica o próprio

\footnotetext{
${ }^{1}$ Ao longo da história dos Estados Unidos, o termo chicano foi usado pelos estadunidenses brancos para referirse à população americana de ascendência mexicana de forma pejorativa. Com o Movimento Chicano nos anos 60,entretanto, a expressão foi apropriada e resignificada pelos "mexican-americans" no intuito de conferir legitimidade política às mobilizações sociais contrárias às políticas racistas e xenófobas direcionadas aos grupos que possuíam algum vínculo com o México nos Estados Unidos.A partir da década de 80, Anzaldúa, junto com outras companheiras chicanas, reconstrói o movimento agregando novas demandas políticas e teóricas que buscavam refletir e dar visibilidade aos problemas de gênero, colonialismo e sexualidades existentes nos EUA e entre os próprios grupos chicanos.

${ }^{2}$ Como solicitado pela revista, todas as citações em inglês de Gloria Anzaldúa ao longo deste artigo foram traduzidas pelo autor.
}

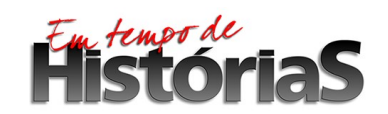


título do livro, Os Mímicos, Isabella era uma ilha onde os homens aprenderam a imitar. A paisagem, os habitantes, o clima, os valores, a cultura, tudo não passava de uma aberração e cópia defeituosa daquele que seria o mundo genuíno, sublime e original: a Grã-Bretanha (Naipaul, 1987).

Por detrás da fábula e metaforização, o romance de Naipaul ganha contornos e ares de realidade, aliás, a obra se trata de uma autobiografia não declarada. Tanto a ilha de Isabella como seu personagem principal possuem uma existência concreta e muito bem localizada: Isabella é a ilha caribenha Trindade e Tobago, Ralph Singh é o próprio Naipaul. Assim como ocorreu com Trindade, Isabella foi uma colônia inglesa - séculos XIX e XX - que conseguiu sua emancipação política apenas ao princípio da segunda metade do século XX. Entretanto, ainda com a independência e a constituição de um novo governo autônomo, do qual o próprio Singh era parte, o novo país não conseguia sair da órbita e zona de influência do mundo inglês: as estruturas e redes de poder do então extinto colonialismo britânico continuavam a delinear a vida política e sociocultural do recente país independente.

Ralph Singh partira rumo à cidade de Londres como quem está à procura de si. Era seu sonho reagrupar os cacos de sua existência fragmentada para reconstituir a unidade do ser. Londres era a promessa da ordem, da pureza, o mito da identidade. Abandonar Isabella e ingressar no coração do mundo metropolitano era uma forma de transformar-se, definitivamente, em um homem autêntico, um homem íntegro, um homem inglês. Ao desembarcar em Londres, entretanto, a identidade inglesa lhe é recusada. Aqueles homens londrinos, brancos e elegantes, os quais Singh tão fortemente admirava, não o reconheciam como um igual, não lhe devolviam a imagem daquele ser ideal que o personagem havia projetado, meticulosamente, em sua cabeça. O sonho de alcançar o status do homem metropolitano não se havia cumprido; Singh continuava a ser um estranho que perambulava errante em busca de um lugar ao mundo.

Ao vir a Londres, a grande cidade, em busca da ordem, do florescimento, da extensão de mim mesmo que deveria ocorrer numa cidade de luminosidade tão miraculosa, eu tentara acelerar um processo que até então parecia estar fora de meu alcance. Eu tentara construir uma personalidade para mim mesmo. Era algo que eu já havia tentado fazer mais de uma vez, e eu esperava ver a resposta nos olhos dos outros. Agora, no entanto, não sabia mais quem eu era; a ambição tornou-se confusa e depois murchou; e quando dei por mim tinha saudades das certezas que tinha no tempo em que vivia na ilha de Isabella, certezas que eu havia desprezado, rotulando-as de naufrágio (Naipaul, 1987:33).

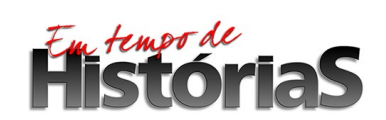


Não obstante, o caminho de volta já não era mais possível. Ao voltar para Isabella, Singh sente cair sobre seu corpo o peso da derrota e do fracasso. Pisar novamente aquelas terras era como confirmar sua condição de exilado, um exílio eterno de alguém que nunca soube o significado de possuir uma casa, de pertencer a um país. Assim como acontecera no Reino Unido, Isabella não podia lhe dar uma identidade, um local onde os destroços da personalidade pudessem ser reerguidos de modo a propiciar coesão e unidade à existência. Os pedaços fragmentados de sua memória apenas lhe lembravam de um tempo em que o ser nunca pôde manifestar-se de forma firme e compacta. Havia entre ele e o solo em que caminhava uma discrepância, um vazio que não permitia ser preenchido, uma contradição que nunca era superada.

Vi através de todas as vigias o azul, o verde e o dourado da ilha tropical. Tão pura e fresca! E eu sabia o quanto ela era horrivelmente artificial; exaurida, fraudulenta, cruel e, acima de tudo um lugar que não era o meu. (...) Voltar tão cedo para uma paisagem que eu julgava ter expulsado de minha vida de uma vez por todas era um fracasso, uma humilhação (Naipaul, 1987:62-63).

O pesadelo de Ralph Singh, entretanto, apenas se iniciava. Como se não bastasse a dor e o sofrimento de regressar a um lugar o qual o personagem nunca havia reconhecido como seu, seus conterrâneos também lhe infligem o estigma de persona non grata. Uma vez em que decide se incorporar ao mundo político do recente país liberto, sua vida começa a cair, paulatinamente, em desprestígio e difamação. Ralph aceita o convite de seu antigo amigo Browne para ser parte da redação do jornal Socialiste de militar no partido fundado pelo companheiro de infância. Ele percebia o quanto era atraente aderir às fileiras do novo partido político e construir uma carreira pública que o associasse à figura de um homem benevolente, um homem rico que se colocava à disposição dos pobres. Era uma forma de se dar continuidade àquela dramatização que sempre fora o eixo de sua existência.

Ralph Singh sabia, entretanto, que entre a nova classe política e aqueles homens ordinários constantemente invocados em nome do povo - ex-escravos, trabalhadores negros famintos, pessoas descalças e sem camisa - havia uma grande mentira, uma encenação política, uma manipulação. A claridade e a percepção com que o personagem enxergava o seu próprio modo de vida e o de seus companheiros, a recusa em doar-se completamente ao partido, em acreditar de maneira cega e ingênua naqueles discursos incendiários que prometiam pôr um desfecho final a todos os males trazidos pelo colonialismo inglês, o

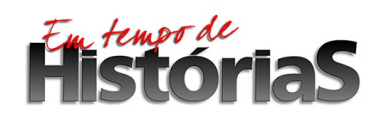


colocavam em uma situação extremamente perigosa e delicada. Ele havia aceitado com gosto o seu novo papel na sociedade de Isabella, mas era incrédulo demais para crer piamente na pureza e inocência da causa pela qual lutavam os demais membros do partido. Ele conhecia muito bem sua condição de mímico, e o novo Estado independente que se erguia na ilha não fazia outra coisa senão reificar essa condição.

O grande pecado do protagonista-narrador, e que o diferenciava dos demais atores que atuavam na ilha caribenha, era que ele havia estado do outro lado da ilha e ultrapassado as aparentes fronteiras monolíticas da identidade (Hall, 2006). Sua instância em Londres lhe havia revelado a não possibilidade do ser, a angústia de se habitar a solidão de um mundo em constante ebulição, o eterno exílio do homem colonizado. A elite política de Isabella, ao reivindicar um status semelhante ao do mundo europeu e querer equiparar-se ao colonizador, se revolta ao ver em Singh sua identidade desvelada, sua qualidade de mímicos escancarada, homens colonizados que renegavam sua própria espécie.

Começam as brigas e acusações. A situação política se torna incontrolável. Após ser enviado à Londres para levar a cabo os procedimentos finais para negociar a nacionalização de empresas estratégicas de Isabella, Singh é definitivamente expulso do partido e acusado de traição. O partido havia encontrado o pretexto que precisavam. Agora, como exilado político e expatriado, o protagonista da obra não vê outra opção senão refugiar-se novamente na cidade metropolitana que o havia abrigado anteriormente.

A história e vida do personagem Ralph Singh nos traz paralelos com a trajetória de outro célebre escritor caribenho, Frantz Omar Fanon.Em seu clássico livro Pele Negra, Máscaras Brancas (2008), o psiquiatra martinicano nos fala sobre o grande sonho das elites martinicanas em se criar um estilo de vida que as associassem diretamente ao mundo francês, mais especificamente àquele vivido na cidade de Paris. Para tal, a mímica continuava sendo o melhor recurso a ser empregado; porém, mais do que simplesmente imitar, era preciso saber como fazê-lo. A língua, nesse processo de simulação, joga um papel fundamental. Como diz Lewis Gordon (2008:15) no prefácio do livro, para Fanon (2008), a linguagem é a promessa do reconhecimento, uma forma de ser admitido dentro de um espaço cultural. Possuir o domínio "correto" da língua é assumir a identidade da cultura.

Desse modo, o primeiro passo do martinicano para identificar-se como francês é pronunciar "corretamente" a língua, isto é, falar francês como um parisiense. Assim como era para o protagonista-narrador de Os Mímicos, que buscava nos olhos do outro, do senhor colonizador, o reconhecimento da identidade almejada, o homem negro de Fanon (2008) 
também procura, por meio da linguagem, ser e existir para um outro, neste caso o homem branco francês. Nesse sentido, apropriar-se da língua do colonizador é também uma forma de se embranquecer, de negar a negritude e sair em busca do encontro com a humanidade do homem branco. Como diz o próprio Fanon (2008:34):

O negro antilhano será tanto mais branco, isto é, se aproximará mais do homem verdadeiro, na medida em que adotar a língua francesa. Não ignoramos que esta é uma das atitudes do homem diante do Ser. Um homem que possui a linguagem possui, em contrapartida, o mundo que essa linguagem expressa e que lhe é implícito.

Ao ter sua humanidade negada pelo olhar colonizador, o negro caribenho se esforça para sair de sua escuridão e adentrar o mundo branco civilizado. Para isso, ele nega a si mesmo, sua cor, sua raça, sua história, sua tradição. Quanto mais ele incorporar os valores da cultura metropolitana, o modo de vida, a língua, a vestimenta, os gostos, as formas de sociabilidade, mais próximo ele estará do ideal de branquitude e ocidentalidade. Ele deseja tornar-se parte da cultura hegemônica, da cultura do dominador, ao final de contas, foram eles, os colonizadores, os que triunfaram os que reinam sobre o mundo e sobre a história (Fanon, 2008).

O negro de Fanon (2008) quer abraçar esse mundo, quer descobrir-se homem, quer transformar-se em branco. No entanto, ao viajar à Paris e imergir nos círculos sociais da vida metropolitana, ele se dá conta da impossibilidade de sua empreitada e se vê na iminência de um fracasso: um martinicano nunca poderá ser um "autêntico" francês. Por mais que ele se esforce, se eduque, fale o francês como um francês, conheça os gostos, o estilo de vida, a forma de vestir-se, o repertório musical, existe uma fronteira radical que é insuperável eintransponível, e essa fronteira é a raça. O martinicano afina de contas, é um homem negro. Ele não o era até pôr os pés na metrópole e ver-lhe revelado, pelo homem branco, sua negritude. Ele se torna negro no mundo dos brancos (Fanon, 2008).

Assim como o foi para Ralph Singh, quando chega a Londres ansioso por encontrar o seu Eu inglês e se depara com a impossibilidade de sê-lo, o ingresso do martinicano à igualdade com seus pretendidos pares franceses não passa de uma ilusão de ótica que agora se desvanece por completo. A respeito disso, Fanon (2008) nos fala sobre sua própria experiência quando de sua primeira viagem à Paris, para estudar psiquiatria. Foi quando o escritor se descobriu negro; até então, em Martinica, ele nunca o havia sido. Antes, em sua

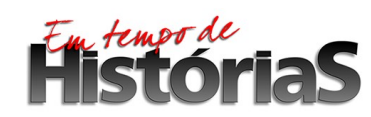


ilha natal, ele era quase um Deus, um homem culto, educado, membro da classe média alta martiniquense. Em seu país, ele eraquase um branco (Fanon, 2008).

No entanto, assim como aconteceu com Ralph Singh, retornar e reintegrar-se à sociedade martinicana já não era mais uma opção. Além de não ser francês, o negro de Fanon (2008) descobre também que já não é mais um martinicano, na acepção hegemônica do termo. A viagem ao exterior, o sonho e o desejo de se tornar o dominador, provocou-lhe algo: um sentido de desorientação e perplexidade diante do mundo e de sua própria terra natal. Seus pares martinicanos o recebem no porto, não sabem muito bem o que esperar, não sabe se volta um "europeu", alguém que quer salientar as rupturas com seu país de origem, ou alguém que quer recuperar os antigos laços que o conectavam com aquela terra a qual agora volta a pôr os pés. Contudo, o martinicano viajante se dá conta de que ele não é nem uma coisa, nem outra. Tanto ele quanto seus pares nacionais percebem que aquele que volta já não é mais o mesmo. Ele transformou-se em alguma outra coisa que ainda não se sabe muito bem o que é, ele passa a portar consigo o estigma da diferença (Bhabha, 2010).

Ele habita agora um mundo intersticial, in-between, um espaço intervalar que o termo Nepantla descreve muito bem. ${ }^{3}$ Ele não está nem aqui, nem lá (Martinica-França), mas sim em um "entre-lugar", no sentido que HomiBhabha (2010) deu ao termo quando pensa na metáfora do poço da escada da artista norte-americana Renée Green: uma zona do "além" que conecta tempos e realidades conflitantes - o andar de cima e o andar de baixo - que se recriam e se chocam continuamente. Ao invés de ser um espaço de confluência, no qual distintos pólos identitários convergiriam para formar uma síntese, o poço da escada se caracteriza por ser um ponto de passagem nebuloso que não chega nunca a concluir-se e a delimitar fronteiras precisas para um novo formato de identidade. Dessa forma, o "entrelugar" é, por excelência, o lugar da indefinição. Ele escapa às tentativas frustradas do olhar colonizador de fixar e estabelecer limites rígidos aos movimentos desordenados e contraditórios da identidade (Bhabha, 2010).

Voltando ao caso de Anzaldúa, deparamo-nos com o mesmo transtorno e crise identitária. A escritora, ao possuir ascendência indígena e mexicana, é uma estrangeira em seu próprio país, os Estados Unidos da América. Ainda que fizesse parte de uma sétima geração

\footnotetext{
${ }^{3}$ Nepantlaé um termo Nahuatl que significa espaço intermediário - in-betweenspace -, uma zona que se situa no meio de duas ou mais extremidades e que indica as liminaridades e potencialidades de transformação de características como o tempo, o espaço, a psique e o intelecto. Anzaldúa (1987) fala de Neplanta, ou das neplanteras - aquelas que facilitam a passagem entre mundos -, como um estado em que os aspectos aparentemente estáveis e inabaláveis da identidade são destroçados e dão forma a novos modos de consciência, que acessam epistemes outras que estão para além da razão branca euro-centrada. Ver: Keating, (2005).
}

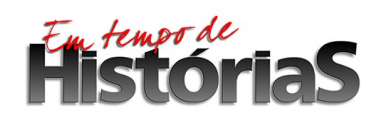


de mexicanos nascidos nos EUA, desde que o expansionismo estadunidense declarou guerra ao México no século XIX e engoliram as antigas fronteiras mexicanas ao norte, a autora não preenche os requisitos identitários de raça e etnicidade solicitados para formar parte do que, para o imaginário hegemônico nacional, seria então o "americano" por excelência: possuir ascendência norte-europeia, protestante, branca e anglo-saxônica (Elizabeth, 2009).

Mais ainda, a condição idiossincrática de Anzaldúa, junto a outros 40 milhões de chicanos que habitam os Estados unidos, ${ }^{4}$ traz à tona outro ponto extremamente desconfortante: se ela é uma estrangeira no país em que nasceu e viveu toda sua vida, estaria ela em casa, então, no país de seus ancestrais? Assim como Fanon (2008) e Naipaul (1987), Anzaldúa (1987) se vê diante do mesmo perigo do retorno. Crescida na cidade de San Antonio, Texas, Gloria se pergunta se seus "pares" mexicanos não lhe infligiriam a mesma hostilidade do não reconhecimento. A escritora chicana confessa sentir medo, medo de não ser acolhida ao querer "voltar" ao México, sua suposta casa. Aceitariam os mexicanos o fato de Anzaldúa haver crescido e se educado inteiramente no país ao norte da fronteira? Logicamente, a resposta é complexa e depende de uma série de fatores que podem ser acionados ou não. Porém, de um modo geral, aos olhos dos mexicanos não estadunidenses, dos que nasceram e viveram toda sua vida do lado sul da fronteira, Anzaldúa será sempre uma estrangeira, uma gringa, uma mexicana a meias, corrompida pela cultura liberal e capitalista dos Estados Unidos (Anzaldúa, 1987).

De fato, a autora chicana nos fala sobre este gesto ao não se ver reconhecida pela comunidade mexicana dentro e fora do México. É porque dentro dela vive também a sua sombra, uma sombra-bestial - Shadow-Beast-que não se reconhece dentro das categorias binárias - Eu-Outro, Homem-Mulher, Branco-Negro, Metrópole-Colônia - que objetificam e alienam o desejo de tornar-se algo distinto às projeções de alteridade e identidade forjadas pelo olho inquisidor do mundo pós-colonial (Henríquez-Betancor, 2012). Por esta mesma razão, sua Besta interior quer romper e implodir os códigos socioculturais erguidos tanto do lado mexicano quanto do lado estadunidense. $\mathrm{O}$ mundo construído à sua volta, não importa o lado da fronteira, é um lugar hostil em que o poder e a autoridade são sempre evocados com o

\footnotetext{
${ }^{4}$ De acordo com o recenseamento demográfico realizado pelo Departamento do censo dos Estados Unidos (US Census Bureau), conduzido entre os anos de 2010 a 2014, a estimativa da população de mexicanosestadunidenses vivendo nos EUA em 2014 era a de 35.4 milhões de pessoas. No entanto, tendo em consideração os altos índices de natalidade entre a população chicana e a alta porcentagem de mexicanos migrantes indocumentados que provavelmente não foram levados em conta, acreditamos que esse número hoje (2016) seja superior e se aproxime aos 40 milhões. Disponível em http://www.migrationpolicy.org/article/mexicanimmigrants-united-states. Acessado em 06/11/2016.
}

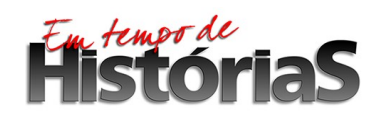


intuito de se preservar o funcionamento da ordem e da lei, punindo e reprimindo exemplarmente aqueles que, por acaso, ousarem transgredi-la ou desafiá-la (Foucault, 1977). $\mathrm{O}$ poder exige que a ferocidade da Besta se mantenha adestrada e adormecida, submissa às premissas essencialistas das etiquetas identitárias que conferem coesão e sentido ao status quo social.

Anzaldúa sente medo. Ela vê que a lógica do poder metropolitano-imperial (EUA) se reproduz também nas sociedades periféricas do mundo pós-colonial (México). Além de relacional (Foucault, 1979), o poder no mundo pós-colonial é flutuante e está sempre em movimento; ele não está circunscrito às linhas da fronteira, ele está aqui e lá, em todo lugar, indo do centro para a periferia (Estados Unidos - México) assim como da periferia para o centro (México - Estado Unidos). O poder se exerce através de múltiplas redes e capilaridades - micros e macros - que não se situam em um ponto fixo, central, mas se articulam e se disseminam por toda a estrutura social, fazendo com que o olho do Rei, o poder do Estado, se reproduza e se faça presente em todos os lados (Foucault, 1979), ao sul e ao norte da fronteira.

Ora, ao conectar-se com sua Besta interna e olhar o mundo através dos olhos despertos e inquietos desta serpente emplumada, Anzaldúa descobre que não é bem-vinda ao mundo, ela não está segura em nenhum lugar. Ainda que ela se esforce para adormecer e apagar o ímpeto interno de sua Sombra-Bestial, em um movimento de desespero em busca de acolhimento e reconciliação com seus ancestrais indígenas e mexicanos, ela sabe que a força da Besta é indomável e pode se insurgir a qualquer momento. O que aconteceria com Anzaldúa se fosse pega de surpresa flertando com as forças obscuras de seu interior selvagem?

E eu pensei quão apto. Medo de ir para casa. E de não sermos acolhidos. Temos medo de sermos abandonados pela mãe, pela cultura, pela Raza, por sermos inaceitáveis, defeituosos, danificados. A maioria de nós, inconscientemente, acredita que se revelarmos este aspecto inaceitável do eu, nossa raça-mãe-cultura nos rejeitará totalmente. Para evitar a rejeição, alguns de nós se conformam com os valores da cultura, empurramos as partes inaceitáveis para dentro das sombras. O que deixa apenas um medo - que seremos descobertos e que a Besta das Sombras escapará de sua jaula (Anzaldúa, 1987:20).

Não, Anzaldúa não quer voltar para casa, até mesmo porque essa casa nunca foi sua, nunca lhe abrigou. Anzaldúa tem consciência dessa impossibilidade. Voltar ao México, ou aos valores que constituem a cultura mexicana, no que diz respeito à homofobia, à cultura do patriarcado, à misoginia, ao colonialismo, ao racismo, seria voltar a um lugar igualmente

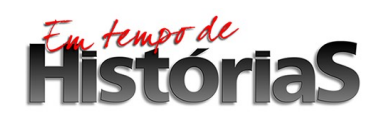


alienante e opressor. Ao perceber-se brown, mulher, lésbica, chicana, queer, Anzaldúa prefere o exílio ao retorno, a viagem à volta, o estrangeiro ao familiar. Antes do que "reconectar-se" com sua ancestralidade, sua história, sua suposta origem, Anzaldúa prefere caminhar pelas penumbras e incertezas de um tempo que reside no além, nas fronteiras intersticiais de um presente saturado de agoras (Benjamin, 2012), um tempo que não assegura nem a continuidade do passado nem a previsibilidade do futuro, mas um constante colidir de temporalidades forâneas que engendram novos deslocamentos de identidade e alteridade (Bhabha, 2010).

A articulação da cultura não se deve à persistência da tradição ou do passado no curso da história; muito pelo contrário, é o tempo presente que, naquela perspectiva criada por Eric Hobsbawn em seu clássico $A$ invenção das tradições (1972), dá sentido e reinscreve as prerrogativas da tradição. Não se trata de realizar uma viagem de redescoberta ou de retorno a uma origem intacta, mas de se entender o legado de uma cultura como "o mesmo em mutação", uma produção que nos capacita a refazer-nos como sujeitos (Hall, 2011:43). Portanto, como diz Stuart Hall (2011:21): "Não é uma questão do que as tradições fazem de nós, mas daquilo que nós fazemos das nossas tradições. Estamos sempre em processo de formação cultural. A cultura não é uma questão de ontologia, de ser, mas de se tornar".

Nesse sentido, Anzaldúa (1987) não se apoia em um mito de origem que condicionaria um desenvolvimento histórico linear e sequencial, como se a origem fosse um princípio fundacional que já contivesse em si os pressupostos estruturantes que dariam unidade e congruência à história (Foucault, 1979). O passado, ou a origem, em Anzaldúa (1987), é como o rizoma de Gilles Deleuze e Félix Gattari (1997), uma falsa raiz que está ramificada em múltiplas linhas de fuga que não se movem verticalmente, de baixo para cima, mas em distintas direções, sem obedecer a uma relação hierárquica de causa-efeito, ação-contrareação. Não existe um centro - uma estrutura - a partir do qual a história estaria centrada e organizada, um eixo gravitacional que delimitaria sua locomoção. A história, assim como o rizoma deleuziano, está atravessada por inúmeras linhas tortas que não convergem a um fim previamente definido, mas criam micro-conexões, relações de intensidade, à medida que se espalham casualmente e estabelecem contato com outras linhas rizomáticas (Deleuze, Gattari, 1997).

O lugar de fala da pensadora chicana se situa nas bordas do presente, nas fronteiras movediças da contemporaneidade. Sua condição fronteiriça, esse estar em permanente contato com diferentes zonas de identidade, faz com que Anzaldúa reivindique e faça outro uso da

\section{Fistortorias}


história, uma história lida a partir de uma perspectiva feminista e queer que resgata o maldito, o alienígena, o abominável, o não masculino. Dessa forma, da relação entre presentefuturo-passado, emerge outra narrativa histórica que quer apropriar-se do passado não mais para subjuga-lo às forças hegemônicas do colonialismo e do patriarcado, mas sim para dar vida às inúmeras vozes que foram silenciadas pelos diferentes padrões de dominação e colonialidade decorrentes do período pré-hispânico, colonial, independente, moderno e póscolonial.

Eu não vendi o meu povo, mas eles me venderam. Então sim, embora a casapermeia cada tendão e cartilagem do meu corpo, eu também tenho medo de ir para casa. Embora defenda minha raça e cultura quando atacados por não-mexicanos, conozcoelmalestar de mi cultura. Eu abomino alguns dos caminhos estipulados pela minha cultura, como paralisa as mulheres, taxando-as de burras,nossas forças usadas contra nós, humildes burras carregando humildade com dignidade. A capacidade de servir, reivindicam os homens, é a nossa mais alta virtude. Eu abomino como minha cultura faz caricaturas machistas dos homens. Não, eu não compro todos os mitos da etnia em que nasci. Posso entender porque, quanto mais matizada de sangue Anglo, mais fortemente minhas irmãs de cor glorificam os valores de sua cultura mestiza,uma forma de compensar sua extrema desvalorização pela cultura branca. É uma reação legítima. Mas não vou glorificar os aspectos da minha cultura que me feriram, e que me feriram em nome da minha proteção (...)(Anzaldúa, 1987:21-22).

E Anzaldúa conclui:

Então não me imponha seus princípios e suas leis. Não me dê seus deuses débeis. $\mathrm{O}$ que eu quero é o reconhecimento de todas as três culturas - branca, mexicana, indígena. Eu quero a liberdade para esculpir e cinzelar meu próprio rosto, estancar o sangramento com cinzas, criar meus próprios deuses fora de minhas entranhas. E se o caminho de casa me for negado, vou ter que me defender e reivindicar o meu espaço, criando uma nova cultura uma cultura mestiza - com a minha própria madeira, meus próprios tijolos e argamassa e minha própria arquitetura feminista (1987:22).

Anzaldúa exige um estado de consciência que não é simplesmente a repetição dos cânones identitários cristalizados pela ação decorrente da história. Assim como Foucault (1979), ela sabe muito bem que o desenrolar histórico é fruto de uma relação assimétrica de forças que se digladiam e buscam legitimar-se diante do mundo ao se apoderar de narrativas que as consolidem no poder. Ela não se sente uma traidora porque, ao abnegar o mexicano e o

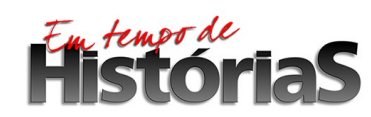


indígena dentro de si, ela nada mais faz do que trazê-los de volta à existência a partir de um novo marco teórico e temporal, o que ela chama de the new mestizaconsciousness. ${ }^{5}$

Longe de ocultar o racismo e o desequilíbrio estruturante de poder que resulta do chamado (des)encontro das raças, a teórica chicana quer reafirmar o antagonismo e a incompatibilidade entre elas, revelando-nos o palco de guerra e as contendas não apaziguadas e imanentes a todo processo de hibridismo étnico e cultural. Anzaldúa (1987) clama por um estado de transição perpétua - o estado de Nepantla e Coatlicue - que não chega nunca a estabilizar-se em um novo modelo de identidade. Do mesmo modo, a zona intempestiva do conflito é uma condição eterna que se arrasta dentro da mestiza e não chega nunca a uma conclusão. Os três referenciais identitários que Anzaldúa situa logo acima - branco, índio, mexicano - são reivindicados apenas e quando transformados e resignificados dentro de uma nova trama histórica e subjetiva.

Nesse sentido, é preciso positivá-los de modo a permitir que eles escapem daquele continuum da História denunciado por Benjamin (2012) e aflorem livres das amarras e estruturas objetificantes do colonialismo e do patriarcado, reconstituindo-se como novas contigencialidades que perturbam e ameaçam a linearidade da trama histórica narrada pelos grupos vencedores. Assim como pensava o filósofo judeu alemão (2012), os mortos não estão tão mortos como o historicismo e as classes dominantes gostariam de imaginar, eles podem se insurgir novamente em qualquer momento de perigo e instante de agora. Por isso Anzaldúa (1987), do mesmo modo que Benjamin (2012) quer implodir a história e ressuscitar os mortos: ela exige que as antigas divindades femininas mesoamericanas renasçam e voltem à vida. Para destruir as diferentes formas de patriarcado, introduzidas no México primeiramente pelos Mexicas (Astecas) e posteriormente pelo patriarcalismo católico do colonialismo espanhol, é necessário reestabelecer o equilíbrio de gênero entre as forças divinas mesoamericanas que existia antes da chegada de Huitzilopochtl- o grande Deus Mexica - e do cristianismo. ${ }^{6}$

\footnotetext{
${ }^{5}$ Essa nova mestiza, entretanto, não deve ser entendida sob o prisma político das doutrinas que foram formuladas no continente latino-americano ao longo dos últimos séculos. Anzaldúa não se propõe a formar uma nova síntese identitaria, uma nova entidade que, como queria Gilberto Freyre no Brasil e Manuel Gamio no México, resultaria de um encontro harmônico entre diferentes raças que eliminariam os caracteres conflitantes e contraditórios, subjacentes a cada uma delas, em favor de uma nova unidade racial. Minha dissertação de mestrado abordou este tema a partir de uma perspectiva crítica ao projeto de identidade e nação mestiça no México pós-revolucionário elaborado pelo antropólogo mexicano Manuel Gamio. Ver: Rodrigues, (2014). Disponível em http://repositorio.unb.br/bitstream/10482/19667/1/2014_RafaelAntonioRodrigues.pdf.

${ }^{6}$ Anzaldúa nos fala que para os povos mesoamericanos, antes dos Astecas se consolidarem como um Estado militar e burocrático, existia um princípio divino de balanceamento sexual entre os deuses. Coatlicue, a Senhora
}

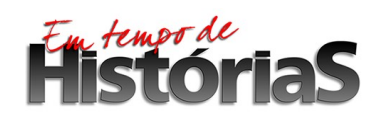


Porém, tal como alertamos antes, voltar à história não significa retornar a uma origem pura e imaculada, significa retomar potências e contigencialidades que apenas cobram sentido quando para colocar a consciência mestiza em movimento, para descontruir a natureza estática do Ser e romper com os arquétipos patriarcais e machistas da colonialidade. A Malinche já não é mais a mulher indígena traidora que se entregou às cobiças do estrangeiro, assim como Guadalupe não é mais a santa católica submissa às premissas patriarcais do cristianismo. Ao reivindicar a mestiza, Anzaldúa (1987) apela para outro mexicano, outro indígena, outro estadunidense. Ela reclama pelas três culturas em que transita: branca, mexicana e indígena, mas não se trata simplesmente de demandá-las tal como elas se encontram à disposição, trata de reerguê-las com outros tijolos e conferir-lhes uma nova natureza.

\title{
O desejo de Ser para transgredir: o devir mutante
}

\author{
No mundo em que me caminho, eu me recrio continuamente. Sou \\ solidário do Ser na medida em que o ultrapasso. \\ Frantz Fanon. Pele Negra, Máscaras Brancas
}

Como explica Grosfoguel (2010), a partir da leitura de Pele Negra, Máscaras brancas, podemos pensar o racismo como uma linha divisória abismal que delimita os limites do humano e do não humano, constituindo duas zonas hierárquicas e conflitantes que, supostamente, definem a humanidade dos homens: a zona do Ser e a zona do não Ser. Todos aqueles que não se enquadram dentro dos arquétipos raciais atribuídos ao homem branco nórdico europeu - indígenas, negros, amarelos, marrons, etc. - estariam relegados a uma não existência que se radicaria na zona do não Ser. Isso quer dizer que eles não seriam considerados homens (humanos) em sua totalidade, que não haveriam realizado o salto da natureza à cultura e que, por esta razão, estariam mais próximos de um estado de animalidade. Assim, por habitarem uma zona de infra-humanidade - leia-se inferioridade -, a prática do racismo e de uma série de atrocidades direcionadas aos povos não brancos e não descendentes de europeus estaria autorizada e legitimada para seguir adiante.

da saia da serpente, era a deusa responsável por manter o equilíbrio entre forças opostas como a vida e a morte, a luz e a escuridão, o masculino e o feminino. Entretanto, a partir da imposição de Huitzilopochtl como nova autoridade religiosa, o venerado Deus da guerra que deu a vitória aos Mexicas sobre os outros povos que habitavam o centro sul do México no século XIV, a milenar linhagem de prestigiosas divindades femininas foi colocada à margem e deu-se início a uma incipiente forma de patriarcado, que se tornou ainda mais voraz com a Conquista e o catolicismo espanhol(Anzaldúa, 1987).

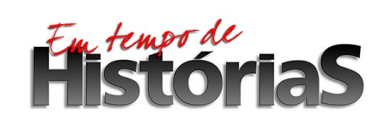


Esses homens não brancos, relegados às margens do ser humano, lutam desesperadamente para sair da zona do não Ser e ingressar à zona do Ser. Como vimos no tópico anterior, eles buscam ansiosamente encontrar nos olhos do homem branco metropolitano um sinal de reconhecimento, algum gesto que os admitam como membros pertencentes à humanidade. Através da mímica, da imitação e do disfarce, as culturas que não portam com elas uma vinculação direta ao mundo branco europeu procuram aproximar-se do ideal de branquitude a partir da apropriação de tudo aquilo que, de alguma forma, as associem a esse mundo de estirpe ocidental: as roupas, as línguas, os valores, a religião, a cultura. No entanto, diante da não possibilidade de se tornar inteiramente humano a partir dos pressupostos fundantes do racismo pós-colonial, o sujeito subalterno cria diferentes mecanismos e estratégias para burlar e desconstruir as categorias da colonialidade e possibilitar, desse modo, outras formas de humanidade.

A emergência de outros gêneros humanos desconstrói a noção universalista e cartesiana do $\mathrm{Eu}$, porque este se fundamenta sempre a partir da criação de uma ausência, uma dessemelhança, algo que o diferencia e que não o constitui como tal, aquilo que ele não é. A constituição do homem branco só ganha concretude e legitimidade a partir da fabricação do seu oposto, sua alteridade, o homem não branco, pois é este último quem o confere coesão e integridade. A construção da alteridade também opera dentro dos mesmos pressupostos: o homem não branco somente cria sentido a si mesmo mediante a construção de seu contraste com o homem branco. Assim, o Outro colonizado passa a ser uma categoria imprescindível na edificação do Eu colonizador, sua diferença é necessária para embasar teoricamente o Ser do homem branco e vice-versa: o Ser do homem não branco precisa que o branco continue existindo como tal para poder afirmar aquilo que o distingue e o caracteriza como outro.

É nesse sentido que a crítica de Bhabha (2010) e Stuart Hall (2011) se propõe a desafiar as pressuposições hegelianas e iluministas das identidades de raça no mundo póscolonial. O problema é quando a reivindicação da alteridade, o desejo de ser algo distinto ao homem branco, coincide com aquela imagem alienante crivada pela mirada do colonizador: a diferença do "outro", constituída pela projeção da alteridade do Eu. Ora, afirmar a si mesmo mediante a reprodução de uma oposição coisificada é continuar girando em torno de uma órbita branca euro-centrada, que é admitida pelo homem branco justamente para confirmar sua autoridade e manter inalterada sua posição de poder. Como afirma Bhabha (2010:86): "Essas identidades binárias funcionam como uma espécie de espelho narcísico do Um no Outro.”. Elas entram em relação não para revelar uma diferença radical e inusitada, mas para 
corroborar com uma dessemelhança previamente configurada que se faz necessária na edificação de $\mathrm{Si}$, dando forma a um delírio maniqueísta, um simulacro de alteridade (Bhabha, 2010).

No entanto, assim como sinaliza a socióloga argentina Karina Bidaseca (2010:35), o processo de mimetização não se reduz a uma mera cópia alienada da figura colonial: "volverseblanco o desaparecer". A mímica criada pelas relações coloniais produz um efeito inesperado que revela uma ambivalência inerente ao discurso colonial. O colono delega ao nativo uma forma parcial de identificação: assimilar os valores e a cultura da metrópole somente e quando elas reifiquem a diferença intransponível marcada pelo corpo não branco do colonizado. O outro é reformado e reconhecido como um "quase o mesmo, mas não exatamente" (Bhabha, 2010:131), pois, ao final de contas, o que de fato o constitui como tal é aquela diferença racial marcada pelo delírio maniqueísta e narcísico de que fala Fanon (2008). O outro é convidado a participar do banquete da civilização desde e quando assuma o lugar de sua diferença - inferioridade - e aceite a impossibilidade de alcançar a "essência" das formas de vida metropolitanas.

A mímica revela-se como uma tentativa frustrada de aproximação com o Eu colonial que acaba por revelar uma nova diferença ao sujeito subalternizado: uma articulação dupla na qual o nativo, ao apropriar-se do Eu metropolitano, se depara com uma alteridade deslizante que não está inscrita e subjugada às normativas da ordem colonial. Assim, no processo de mímica se instaura uma nova forma de subversão que se caracteriza também pela negação e recusa da identidade. O colonizado, ao reencenar os valores e modos de vida metropolitanos, toma consciência da inautenticidade do Eu, do simulacro e da teatralidade que caracterizam a sociedade que o rodeia; a imitação se faz necessária agora não mais para querer alcançar esse status “inabalável” atribuído ao homem branco, mas sim para burlar as próprias categorias identitárias que constituem o mundo pós-colonial.

A mimese em Bhabha (2010) se constitui como um desejo de subversão, de negação. Assim como em um cenário de guerra, os dominados, esses homens mais frágeis e vulneráveis à violência, se utilizam da mímica como estratégia de sobrevivência. Eles desenvolvem a habilidade de se camuflarem, de passarem desapercebidos quando o precisam, de se confundirem com o meio e a natureza à sua volta, de se transformarem em brancos e não brancos quando assim for necessário. Como dizia Lacan (apudBhabha, 2010:129): "Não se trata de se harmonizar com o fundo, mas contra um fundo mosqueado, ser também mosqueado - exatamente como a técnica de camuflagem praticada na guerra dos homens".

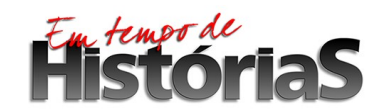


Sim, o colonizado quer ser o colonizador, mas não para repeti-lo senão para transformá-lo e ultrapassá-lo, para desestabilizar sua suposta superioridade e invencibilidade, para subverter as regras do jogo, para evidenciar as contradições e ambiguidades intrínsecas à ordem colonial. "Seja como Eu, mas não se aproxime tanto, seja diferente, mas apenas quando essa diferença não ponha em xeque minha própria identidade". Este é o modus operandi do esquema colonial. O homem subalterno, entretanto, está agora no além, ele se defronta com uma nova alteridade que não está mais fixada nos pressupostos essencialistas e dicotômicos da identidade. Seu contínuo deslocamento, sempre deslizando entre as fronteiras do Ser e do não Ser, da colônia e da metrópole, o coloca em uma posição de constante movimento que não pode ser mais previamente definida, e assim, consequentemente, os mecanismos de dominação se tornam obsoletos e ineficientes porque já não conseguem dar respostas precisas a essas novas configurações identitárias.

Ora, aqui está o cerne da discussão da nova consciência mestiza de Anzaldúa (1987). Assim como dito por Fanon (2008) e Grosfoguel (2010), existe de fato uma linha racial que separa hierarquicamente os homens entre si de acordo às suas vinculações ou não vinculações a uma humanidade branca euro-centrada. Nesse sentido, obviamente, Anzaldúa clama que todos os homens na face da Terra tenham sua humanidade reconhecida e usufruam igualmente de todos os direitos conferidos ao ser humano. No entanto, poderíamos dizer que Anzaldúa clama pela zona do Ser mas não pelo Ser em si, pois, ao invés do Ser, ela clama por um devir, um devir mutante. Ela quer o humano, mas ela fala de outra humanidade, porque ela não se reconhece apenas como homem, mulher, lésbica, indígena, brown, mexicana, chicana, estadunidense ou queer. Ela também reivindica seu lado natureza-animal, o peyote, o porco, a serpente, a víbora, as montanhas, as árvores, o vento e as pedras (Anzaldúa, 1987).

A autora nos fala sobre o papel fundamental de suas experiências psíquicas e espirituais com realidades sobre-humanas e extra-sensoriais: a natureza, os animais, espíritos, entidades divinas e realidades extramundanas. Todos aqueles que foram expulsos do mundo convencional estão mais aptos para desenvolver a faculdade de pensar através dos sentidos e outros modos de inteligência que não passam pela racionalidade branca. Assim, também como estratégia de sobrevivência em um mundo branco que lhe é hostil, Anzaldúa desenvolveu um sexto sentido, um sentido que se comunica com imagens e símbolos, entidades e forças extra-humanas que lhe deram novas habilidades e outras formas de perceber o mundo, shifts in perception, para empreender uma viagem - latravesía - para além de si (Lugones, 2005).

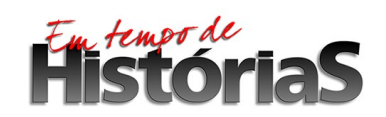


Cada ganho de consciência, cada passo adiante é uma travesía, um cruzamento. Eu sou uma estrangeira em um novo território. E novamente, e novamente. Mas se eu escapar desta tomada de consciência, fugir conscientemente, eu não estarei mais me movendo. $\mathrm{O}$ conhecimento me faz mais consciente, me torna uma pessoa mais lúcida. O conhecimento é doloroso porque não permite que eu permaneça confortavelmente no mesmo lugar. Eu não sou mais a mesma pessoa que eu era antes(Anzaldúa, 1987:48).

Este estado de Travesía coloca Anzaldúa em contato com forças e potências que estão más allá das fronteiras do humano. Ela faz de Coatlicue, a antiga divindade feminina mesoamericana, o seu novo estado de consciência: uma ruptura na vida cotidiana que a imerge na escuridão da alma e a coloca diretamente em contato com Miktlán, o mundo subterrâneo, os aspectos inframundanos da psique e do inconsciente. Diante de Coatlicue, Anzaldúa se metamorfoseia em víbora, ganha corpo e pele de serpente. Passa a ver o mundo a partir de novos olhos, pupilas dilatadas, uma dentição especializada repleta de peçonhas.A animalidade se apossa de seu corpo e Anzaldúa já não oferece nenhuma resistência, pois ela sabe que seu devir animal, sua condição neplantera, apesar de toda dor envolvida no ato de transformação, lhe dota de novos poderes que estão para além do meramente humano (Lugones, 2005).Sobre isso, a autora (1987:50) diz: “Tremo diante do animal, do alienígena, do sub ou supra-humano, do eu que tem algo em comum com o vento, com as árvores e as rochas, que possui uma determinação demoníaca e uma crueldade além do humano".

Anzaldúa regressa às formas de natureza e animalidade que a racionalidade branca racista insistiu em associar a uma infra-humanidade. Ao invés de rejeitá-las, a ativista chicana positiva seu aspecto natureza-animal e cria as condições necessárias para cruzar os caminhos não permitidos do humano e não humano. Esse novo estado de consciência, a cada novo estágio de transmutação, faz com que seu corpo adquira novas formas de sensibilidade e compreensão do mundo que não para de expandir-se. Sua reivindicação de humanidade, portanto, não perpassa pelo crivo cientificista daquela divisão binária estabelecida pelo Ocidente entre natureza e cultura. O artifício da mímica e o desejo pelo Eu do outro, pelo Eu metropolitano, se dá justamente para desmontar a lógica binária do poder colonial e negar suas prerrogativas asfixiantes de identidade e alteridade. $\mathrm{O}$ homem mutante deseja outra coisa, ele está em outro lugar. Ele implode a idealização de um Eu-Outro delimitados pelas fronteiras narcísicas da identidade e se lança para o além, um tempo que se situa às margens e

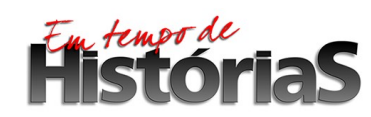


nas bordas do "tempo vazio e homogêneo do capitalismo" (Benjamin, 2012) e da colonialidade.

\section{Considerações finais}

Não existem um Eu e um “outro" pré-fabricados, eles se formam e se transformam ao travar contato entre si. Não partimos mais daquele princípio instituído pelo modelo dialético hegeliano de que haveria uma tese, uma antítese e uma síntese. A síntese que poderia resultar desse encontro não é um produto harmônico que haveria superado suas contradições, ela se constitui em um devir que é indizível-inominável e que continua a carregar contradições que são intransponíveis e insuperáveis. Por isso ele não se constitui em uma nova síntese. Ele não logra alcançar uma estabilidade que engendre uma identidade final, acabada. "O sujeito de desejo nunca é simplesmente um Eu Mesmo, o Outro nunca é simplesmente um Aquilo Mesmo" (Bhabha, 2010:86). Os seguintes andares que formam o poço da escada de René Green não formam identidades muito bem delimitadas, antes mesmo de entrar em contato eles já deixaram de ser aquilo que eram antes. Como diz Anzaldúa (1987:80): "Embora seja uma fonte de dor intensa, sua energia vem do movimento criativo e contínuo que não cessa de quebrar o aspecto unitário de cada novo paradigma".

Não interessa a Anzaldúa voltar para casa, mas não lhe interessa tampouco permanecer-se imóvel nos Estados Unidos. Habitar a fronteira é como habitar um trem em constante movimento. Anzaldúa não está nem aqui, nem lá, ela está viajando dentro deste trem que recorta e percorrem diferentes zonas fronteiriças e regimes de temporalidades, ela está sempre em um "entre-tempo" e um "entre-lugar". Assim como colocado por Fanon (2008:190) na epígrafe do tópico anterior, Anzaldúa também é solidária do Ser, mas somente e quando ela o ultrapassa, porque o Ser não pode nunca se constituir como fim, o destino final da viagem, mas sim como meio, um ponto de passagem. O Ser não lhe congela os movimentos e não paralisa a força propulsora deste trem em que Anzaldúa viaja, a autora continua a transitar entre mundos e percursos inabitados e desconhecidos.

Nesse sentido, o escritor martinicano nos lança o seguinte desafio: "O que quer o homem? O que quer o homem negro?” (2008:190). Sua resposta é a de que o homem quer ser livre, livre das opressões de raça, de gênero, de classe, de nacionalidades, livre de todo tipo de amarras forjadas no mundo pós-colonial. E o homem fanoniano é livre inclusive para não se fixar dentro dos estereótipos raciais narcisistas fabricados pelo próprio homem negro e pelos

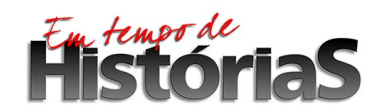


movimentos de emancipação anticolonial, porque a partir do momento em que eles engessam e essencializam o homem dentro de um novo arquétipo de identidade eles acabam por reproduzir novas formas de domínio e alienação. Por isso Fanon clama pela liberdade do homem de se estar solto no mundo e não se enclausurar nem em uma negritude, nem em uma branquitude, apesar do fato de que, sim, o homem também deve ser livre para fazer uso e reivindicar o negro e a negrura (blackness), desde que não caia em essencialismos e não o sufoque dentro dos calabouços da homogeneidade. Como diz o próprio Fanon (2008:188190):

\footnotetext{
Não é o mundo negro que dita minha conduta. Minha pele negra não é depositária de valores específicos. (...) Não existe missão negra. Não existe fardo branco. (...) Não tenho o dever de ser isso ou aquilo... Se o branco contesta minha humanidade, eu mostrarei, fazendo pesar sobre sua vida todo o meu peso de homem, que não sou esse y'abonbanania que ele insiste em imaginar. (...) Um único dever: o de nunca, através de minhas opções, renegar minha liberdade. Não quero ser a vítima da Astúcia de um mundo negro. Minha vida não deve ser dedicada a fazer uma avaliação dos valores negros. Não sou prisioneiro da História. Não devo buscar nela o sentido do meu destino. (...) Não se deve tentar fixar o homem, pois o seu destino é ser solto. A densidade da história não determina nenhum de meus atos. Eu sou meu próprio fundamento. É superando o dado histórico, instrumental, que introduzo o ciclo de minha liberdade.
}

Fanon (2008) demanda uma História que não carregue consigo o fardo do passado, como se o presente e o futuro estivessem condenados a um desencadeamento histórico teleológico e sequencial que interrompesse a imprevisibilidade do momento de agora. Anzaldúa, do mesmo modo, clama por uma história na qual o mexicano e o indígena possam ser reinventados e repousem em uma alteridade radical em relação ao que foram no passado, de tal modo que seus ancestrais indígenas possam ser simultaneamente, exigidos e renegados. É por isso também que o indígena e a mexicana pelo qual Anzaldúa reclama nunca poderão ser uma figura congelada, pois eles estão sempre em movimento, transmutação. Aprisionar-se dentro do indígena e da mexicana pode ser tão sufocante como viver sob a égide do racismo estadunidense, e Anzaldúa e Fanon, a partir de suas distintas experiências com os paradigmas da colonialidade, sabem muito bem disso.

Sim, é preciso reivindicar a zona do Ser, mas somente e quando ela não se constitua em uma categoria ontológica e engessada que impossibilite os movimentos nômades do devir. Não se trata de clamar por uma humanidade estática e petrificada, que possui o homem

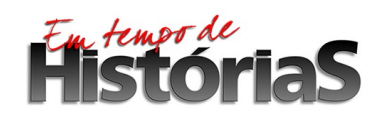


branco como centro e o não-branco como o seu contraponto, o seu reflexo indispensável. Tampouco, se trata de erguer uma nova centralidade que faça com que os grupos brancos troquem de posição com os não brancos e sejam realocados para a periferia. Quer-se aqui justamente desconstruir a lógica binária e esquizofrênica que possibilitou o surgimento de um Eu-Outro - Branco-Não Branco - para potencializar a emergência de grupos desviantes que desestabilizem essa ordem dicotômica.

Há que se trazer à tona aquela perspectiva fanoniana do desejo quando diz que "o verdadeiro salto consiste em introduzir a invenção na existência" (2008:189-190). Há que se redesenhar um novo horizonte de alteridade que assuma seu caráter intempestivo e inusitado, um devir mutante e neplantero que ameace e escape às tentativas colonizadoras de fixar e delimitar os movimentos imprecisos e imprevisíveis do desejo e da diferença (Lugones, 2005). A luta por habitar a zona do Ser e por ser reconhecido como humano não deve passar pelo crivo do olhar branco e por seu humanismo cartesiano, mas sim construir-se na edificação de um homem plural e multifacetado que não precisa mais do consentimento de uma razão euro-centrada para emergir no mundo.

\section{Referências Bibliográficas}

ANZALDÚA, Gloria. Borderlands - La Frontera: The New Mestiza. San Francisco: AuntLute, 1987.

BIDASECA, Karina. No hay otro del otro. La construcción de la alteridad y la representación del otro. Entre el Eurocentrismo y Los Estudios Poscoloniales In: Perturbando el texto colonial. Los estudios (pos)coloniales en América Latina. Buenos Aires: Ed. SB, 2010.

BENJAMIN, Walter. Sobre o conceito da História In: $O$ anjo da história. Belo Horizonte: Autentica editora, 2012.

BHABHA, Homi K. O Local da Cultura. Belo Horizonte: Editora da UFMG, 2003.

DELEUZE, Gilles e GUATTARI, Félix. 1995-1997. Mil Platôs. Capitalismo e Esquizofrenia. Rio de Janeiro: Editora 34, 1997.

ELIZABETH, Theiss-Morse. Who counts as an American? The boundaries of National Identity.Cambridge: Cambridge University Press, 2009.

FANON, Frantz. Pele Negra, Máscaras Brancas. Salvador: EDUFBA, 2008.

FOUCAULT, Michel. Introdução: Por uma genealogia do poder. I. Verdade e poder. II. Nietzsche, a genealogia e a história In: Microfisica do Poder. Tradução de Roberto Machado. Rio de Janeiro: Edições Graal, 1979.

. Vigiar e Punir. Petrópolis: Vozes, 1977.

GROSFOGUEL, Ramón. La descolonización del conocimiento: diálogo crítico entre la visión descolonial de FrantzFanon y la sociología descolonial de BoaventuraSantos. In: Actas del "IV Training Seminar del Foro de Jóvenes Investigadores en Dinámicas Interculturales" del Centro de Estudios yDocumentación Internacionales de Barcelona (CIDOB), Barcelona, 2011.

HALL, Stuart. Da Diáspora. Identidades e Mediações culturais. Belo Horizonte: UFMG, 2011.

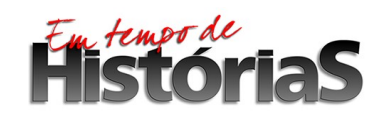

(PPGHIS/UnB) No. 30, Brasília, Jan - Jul 2017 ISSN 2316-1191 
. A identidade cultural na pós-modernidade. Rio de Janeiro: DP\&A Editora, 2006.

HENRÍQUEZ-BETANCOR, María. Anzaldúa and "the new mestiza": A chicana dives into collective identity". Language Value 4 (2), 38-55. Jaume I University ePress: Castelló, Spain, 2012.

HOBSBAWM, Eric. Ranger, Terence (Orgs.). A Invenção das tradições. Rio de Janeiro: Paz e Terra,1997.

KEATING, AnaLouise. Introduction: Shifting worlds, una entrada In: Entre Mundos-Among Worlds: New perspectives on Gloria E. Anzaldúa. New York: Palgrave Macmillan, 2005.

LUGONES, María. From within Terminative Stasis: Creating Active Subjectivity, Resistant Agency In: Entre Mundos-Among Worlds: New perspectives on Gloria E. Anzaldúa. New York: PalgraveMacmillan, 2005.

NAIPAUL, Vidiadhar Surajprasad. Os Mímicos. São Paulo: Companhia das Letras, 1987.

RODRIGUES, Rafael Antonio. (2014). A temporalidade da nação. A negação do outro. México, indigenismo e regime revolucionário (1920-1940).

Disponível

em

http://repositorio.unb.br/bitstream/10482/19667/1/2014_RafaelAntonioRodrigues.pdf. 